\title{
Self-Employed Women In A Mega-City Setting: Women At The Cross-Roads Of Patriarchy, Poverty, And Progress In Karachi.
}

\author{
Nasreen Aslam Shah \\ \& \\ Muhammad Faisal Zia \\ Department of Social Work \\ University of Karachi
}

\begin{abstract}
This paper presents a critical study of self-employed women conducted in selected towns of Karachi. The nine hundred women who participated in this study were found living and working in the squatter settlements where basic amenities of life are almost not existent; with no outside assistance, in the form of loans, skill development and legal protection, these women are left to fend for them. Karachi in many ways mirrors the real image of Pakistan- a country whose development progress is marred by flawed institutions, diminishing democratic principles, under utilization of human and natural resources and is now caught in a fierce struggle for its survival. This paper seeks to answer some pertinent questions: what is progress? How it is achieved? Is patriarchy and poverty elimination one of its goals and strategies? If yes, would the country ever make a breakaway from the clutches of patriarchy-poverty giant? How do they perceive themselves - as oppressed under the weight of multiple roles? Or do they feel emancipated and liberated because of their role as providers for their family needs? Or are they doubly exploited by the patriarchal system? In short, what is the nature of the work they do to earn money? This study drawing upon field research conducted in nine towns, selected out of the total of eighteen towns of Karachi, seeks answers to these questions by exploring self-employed women workers' experiences and perceptions about their status and roles.

To find answers to these questions, the researchers applied a combination of methods. Nine hundred women were randomly selected to answer a questionnaire. Data was collected from primary and secondary sources. The findings of the research confirmed that the level of poverty has visibly increased, women are more aware of patriarchy and how it manifests itself in their lives, and finally they are convinced that progress and development remain far away from them.
\end{abstract}

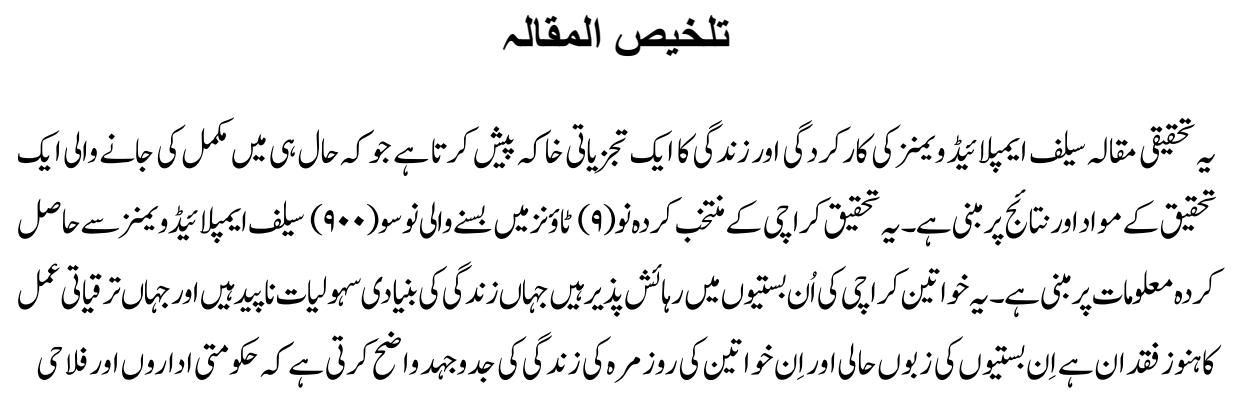



and Progress in Karachi.

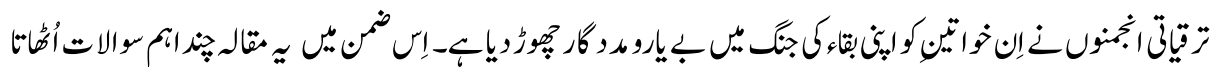

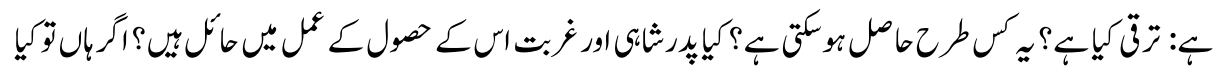

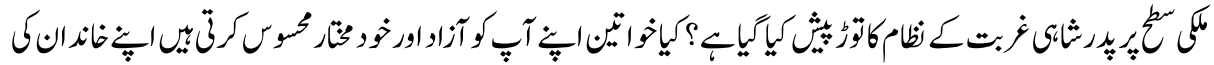

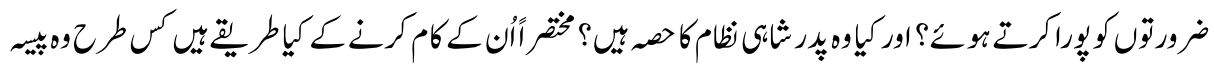

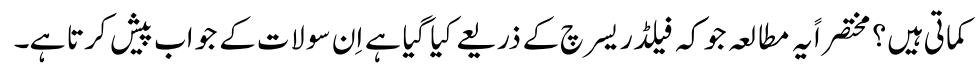

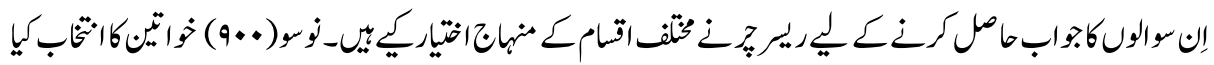

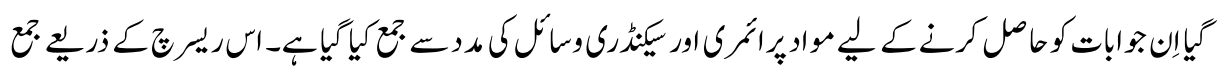

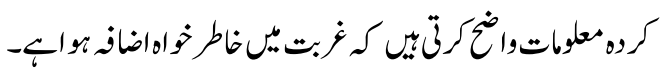

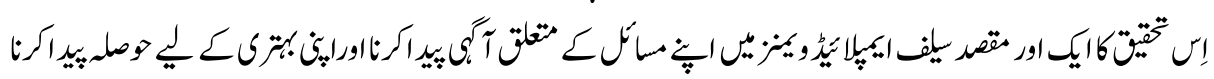

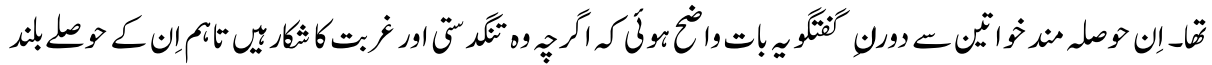

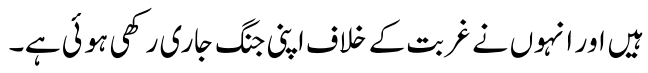

\section{Introduction}

The $20^{\text {th }}$ century saw a dramatic global increase in the number of women in the labour force. Women's participation in labour force either as self employed workers is not a recent phenomenon but 'its historic roots can be traced to the traditional family-based occupations in rural economies and integrated livelihoods which were land-based, cattlebased and home based' as observes Shalini Sinha in her study Rights of Home-based Workers, a study conducted in the context of the Indian situation. In the past women undertook works like dairying, basket and mat making, weaving etc. either for the consumption of the household or for the local market. The rapid decline of the formal sector which caused loss of jobs by a large number of workers, Sinha's study assigns this as a factor pushing workers into informal work, including home based( Sinha, 2006, p 14).

It took four years to collect data, observing the life patterns of these women, spending long hours at their houses and doing corner meetings. During these years a strong understanding and bonding with these women was developed by the researcher. The sample size for the study was 900 self-employed women from 9 towns of Karachi. The towns included New Karachi, Liaquatabad, SITE, Orangi, Lyari, Gulberg, Gadap, Baldia and North Nazimabad.

The self-employed women who are focus of this research study are mostly huddled in slums of metropolitan city of Karachi. Here they are living a ghetto style life. Belonging to the lower-strata of income (and this also means lower social hierarchy) these females 
of all ages remain engaged in income generation. These women are really struggling hard to thrive and boost their livings by supporting their families before or after marriages. Some of them are working from the age of 15,16 or 20 years and then they never looked back. According to the research findings the age groups of these women could be seen in the following table:

Table $-\mathbf{A}$

Distribution of the respondents according to their age group

\begin{tabular}{|l|c|c|c|c|c|c|c|c|}
\hline Towns & $\begin{array}{l}\text { Up to } \\
\mathbf{1 5} \\
\text { years }\end{array}$ & $\begin{array}{l}\mathbf{1 6}-\mathbf{2 0} \\
\text { years }\end{array}$ & $\begin{array}{l}\mathbf{2 1}-\mathbf{2 5} \\
\text { years }\end{array}$ & $\begin{array}{l}\mathbf{2 6}-\mathbf{3 0} \\
\text { years }\end{array}$ & $\begin{array}{l}\mathbf{3 1}-\mathbf{3 5} \\
\text { years }\end{array}$ & $\begin{array}{l}\mathbf{3 6}-\mathbf{4 0} \\
\text { years }\end{array}$ & $\begin{array}{l}\text { More } \\
\text { then 40 } \\
\text { years }\end{array}$ & $\begin{array}{l}\text { Row } \\
\text { Total }\end{array}$ \\
\hline New Karachi & - & $30(30 \%)$ & $09(9 \%)$ & $12(12 \%)$ & $11(11 \%)$ & $15(15 \%)$ & $23(23 \%)$ & 100 \\
\hline Liaquatabad & - & $32(32 \%)$ & $08(8 \%)$ & $12(12 \%)$ & $15(15 \%)$ & $16(16 \%)$ & $17(17 \%)$ & 100 \\
\hline SITE & - & $18(18 \%)$ & $09(9 \%)$ & $11(11 \%)$ & $14(14 \%)$ & $14(14 \%)$ & $34(34 \%)$ & 100 \\
\hline Orangi & - & $45(45 \%)$ & $11(11 \%)$ & $11(11 \%)$ & $08(8 \%)$ & $14(14 \%)$ & $11(11 \%)$ & 100 \\
\hline Lyari & - & $13(13 \%)$ & $12(12 \%)$ & $09(9 \%)$ & $16(16 \%)$ & $12(12 \%)$ & $38(38 \%)$ & 100 \\
\hline Gulberg & $07(7 \%)$ & $19(19 \%)$ & $10(10 \%)$ & $16(16 \%)$ & $11(11 \%)$ & $12(12 \%)$ & $25(25 \%)$ & 100 \\
\hline Gadap & $08(8 \%)$ & $23(23 \%)$ & $13(13 \%)$ & $19(19 \%)$ & $15(15 \%)$ & $07(7 \%)$ & $15(15 \%)$ & 100 \\
\hline Baldia & - & $36(36 \%)$ & $09(9 \%)$ & $11(11 \%)$ & $08(8 \%)$ & $10(10 \%)$ & $26(26 \%)$ & 100 \\
\hline $\begin{array}{l}\text { North } \\
\text { Nazimabad }\end{array}$ & - & $34(34 \%)$ & $15(15 \%)$ & $13(13 \%)$ & $12(12 \%)$ & $08(8 \%)$ & $18(18 \%)$ & 100 \\
\hline Column total & 15 & 250 & 96 & 114 & 110 & 108 & 207 & 900 \\
\hline
\end{tabular}

Table $-\mathrm{A}$ is showing distribution of the respondents according to their age group. 250 are of the young ladies fall in the group $16-20$. The second highest groups of self employed women of 207 respondents fall in the category of more than 40 years of age.

Thus a never ending fight against poverty starts once they step in the establishment of their businesses. The reasons for not recognizing the work of self employed women is that majority of them are illiterate and lack of confidence. The inequalities in the lives of these women start at the very young age. It is amazing to watch little girls busy in helping their mothers and grandmothers in a variety of work. As little girls they do not go to school and like their mothers and grandmothers one day would be counted in the list as adult illiterates and as self-employed women. Becker pointing out that the engagement of boys and girls in the informal economy poses a major concern in South Asia and Africa where it is widespread. Becker writes that this work by children 'suggests a connection between the level of economic development and work of children' (Becker, 2004).

As told by themselves, these women do not complete their primary or secondary education because of poverty and also because of the gender hierarchies. Being a working woman they have dreams regarding their family and children. Sadly, very few of them can hardly provide even the primary education to their children and at last they would also become the part of this scuffle. 
Self-employed Women in a Mega-city Setting: Women at the Cross-roads of Patriarchy, Poverty, and Progress in Karachi.

The need for substantial caregivers while mothers are at work places many children most often girls - at risk of being kept out of or dropping out of school in order to care for younger siblings or perform household work, or both. The universally recognized rights of children to play, to receive an education and to be cared for by both parents are at risk, with negative implications for their well - being and future economic status. Evidence of these trends is consistent across many developing countries. Similarly in countries in South-East Asia, as more mother works outside the home, the increased need for child care is met by older children, aunts and grandmothers, who often become the primary caregivers of young children in rural areas (Illahi2001, Kamerman2002).

Besides having all these problems still more women are now taking up self-employment. This is also happening in the strongest economies of the world. A recent study conducted in the US shows that employment rates for women have proportionally increased over the last 35 years, compared with men's self-employment (Gurely-Calvez et.al, 2009).

Field visits have shown how the self-employed women suffer from the constraints caused by lack of knowledge and information, social skills and networking. With no education and no formal training, these women would have no chance to find employment in the formal sector and therefore, would remain engage in generating their own income and employment within their homes with allusive resources and diminishing capital in view of accelerating poverty. According to the findings of this research very few selfemployed women of Karachi are able to take up vocational training.

Table - B

Distribution of the respondents according to have they acquired any professional training

\begin{tabular}{|l|c|c|c|c|}
\hline Towns & Yes & No & Incomplete & Row total \\
\hline New Karachi & $03(3 \%)$ & $97(97 \%)$ & - & 100 \\
\hline Liaquatabad & $08(8 \%)$ & $92(92 \%)$ & - & 100 \\
\hline SITE & $13(13 \%)$ & $87(87 \%)$ & - & 100 \\
\hline Orangi & $11(11 \%)$ & $89(89 \%)$ & - & 100 \\
\hline Lyari & $23(23 \%)$ & $77(77 \%)$ & - & 100 \\
\hline Gulberg & $06(6 \%)$ & $94(94 \%)$ & - & 100 \\
\hline Gadap & $33(33 \%)$ & $67(67 \%)$ & - & 100 \\
\hline Baldia & $12(12 \%)$ & $88(88 \%)$ & - & 100 \\
\hline North Nazimabad & $13(13 \%)$ & $87(87 \%)$ & - & 100 \\
\hline Column total & 122 & 778 & - & 900 \\
\hline
\end{tabular}

Table - B explains whether the respondents made any effort to upgrade the quality of their work by taking skill development or training courses. 778 out of 900 did not take any such training.

Regardless of the historic truth that women have always worked both within and outside the household women's work remains unacknowledged and little effort is made to 
document whatever they do either as housewives or as family bread earners. Further more, irrespective of the nature of their work or the hours they spent at the work place, women's work also remains under-enumerated and under-remunerated.

In a recent study conducted in India where women's situation is closely similar to that in Pakistan, Sunny Jose found that social norms constrain women from taking up paid work. This research also noted that "by treating women's participation in paid work away from the homes as something aberrant to what is being considered as appropriate and ideal for womanhood, social norms actively discourage and devalue women's participation in, as well as limit their opportunities for, paid work (Jose,2007).

The recent study on the Progress of the World's Women 2008-2009 published by the United Fund for Women (UNIFEM) once again highlights the fact how poverty and insecure employment, especially home based work are strongly linked despite the fact that these employments usually lack social protection, and pay is usually too low to generate savings (UNIFEM, 2009).

Organisations working in the field of promoting informal economy realised that its time to take an affirmative action towards the betterment of self-employed women. The credit goes to the Self Employed Women's Association (SEWA) of India and international alliance of home based workers (HomeNet) to draw attention to the lack of statistics regarding home based workers in the informal economy(ILO ,2002). Subsequently this venture in the sphere of informal economy led to the formation of a global network called Women in Informal Employment: Globalizing and Organizing (WIEGO) with the fivepoint agenda, one of which is to improve and develop statistics on the informal economy (ILO ,2002).

The situation of self-employed women workers in Pakistan suffers both from the nonrecognition of their labour and hence the non-recognition of the contribution they make to the nation's economy and to the family's income, and also from poor and inconsistent statistics. An ILO study conducted in 2002 that the home based or self employed workers are the least organised and least visible among the informal workforce groups. Although women are the dominant majority in the self-employment sector of Pakistan yet their work in the informal economy remains invisible and lacks in organization. Is it because of the gender factor?

Basically this is also one of the reason behind selecting this topic to explore the existence of any link between women' self-employment and the level of freedom and agency that they might have acquired in areas such as the decision making power regarding the running of the home life, reproduction, enhancement their self prestige being woman, and social justice for women. Females belonging to families in which men's earnings are 

and Progress in Karachi.

insufficient to meet the cost of daily needs, in addition to their traditional work within the family, seek paid work to get 'little' money for their family's income. This work is done in addition to their traditional work of nurturing and caring for the family. It is interesting to note that traditionally women are 'allowed' to have the 'freedom' to work but have no or little control over their wages. Males of their families, and even older women, particularly the mothers-in-law, believe that money in hand breeds social freedom among women.

\section{The Self-Employed Women}

A recent study on home based/self employed workers defines home based workers as 'those who work from their homes. In this case their home is also their work place. This category does not include those workers who gather at another person's house to carry out some tasks. In terms of type of employment, home based workers are primarily of two types - self employed /own account workers; and piece-rate/ home-workers/ industrial out-workers(Home Net Soth Asian and Institute of Social Studies Trust, 2006).'

To sum up, home based workers refer to three type of workers "who carry out remunerative work within their homes- dependent subcontract workers, independent own account producers, and unpaid workers in family businesses (Sinha,2006, p.17).

A self-employed woman worker irrespective the way her work category is defined, depends on men of her family or the middleman. This dependency in procuring raw materials, equipment, tools and market for their products deprives women of recognising their agency. The money they earn thus gets into the pockets of men first; women get what men decide to give them, if at all. Maria Mies (1982) identified the exploitative nature of this category of work which is produced by women inside the homes and sold by men outside the home.

Explaining this in the context of the lives of women lace-makers of Nasrapur, in South India, Mies observed that women's lace-making work at home "led not only to class differentiation within particular communities (Christians, Kapus) but also to the masculinization of all nonproduction jobs, especially of trade, and the total feminization of the production process. ... Men sell women's products and live on the profits from women's work' (Mies, 1982, p.10).

The Home Net South Asia, a network of home based workers, in a study defined home based workers strictly as those who work from their own homes. 'This category does not include those workers who gather at another person's house to carry out some tasks. In terms of type of employment, home based workers are primarily of two types - self 
employed/own account workers, and piecerate/homeworkers/ industrial outworkers (Doanne, 2007).

In this paper, the terms home-based working women, self employed woman and piecerate woman worker has been used interchangeably. There are multiple reasons for this. The field experience and discussion with self-employed women are convincing enough that instead of coping with words and phrases and labels for determining the category and nature of work women are engaged in, one must listen to the voice of women themselves. During the research when they were asked about the nature of their work that 'What difference does it make?' they asked instead of answering any question:

\section{'Call it whatever you fancy; we work because it brings us money. We are not beggars.'}

What they knew well was the ground hard reality that they must work, in addition to their routine household drudgery and reproductive role, because they must earn to save themselves (their children and family) from a street-dog's life.

Martha Chen's observation that the work of women with low-income, across most regions and social groups 'remains invisible, small-scale, unprotected, undercapitalized and, therefore, of low-return, low-productivity, and low-growth' (Chen, 1996) also encouraged me to conduct an in-depth research related to the self-employed women of Karachi and see how the situation here fits with Chen's description. While designing this research project much insight was gained from Carr, Chen and Tate's paper in which they advocate four interrelated and multidirectional strategies for studying home based work. These are:

i. "to document the number, contribution, and working conditions of home based workers and to assess the impact of globalization on them";

ii. to help home based workers gain access to - and bargain effectively within - labor and product markets (both local and global)";

iii. to increase the visibility and voice of home based workers and other women workers in the informal sector"; and

iv. "to promote an enabling work and policy environment for home based women workers" (Carr, 2000).

The other objective of this survey-based study is to collect information on the social life style of these women. In this regard the foremost is their health status the following table shows it: 
Self-employed Women in a Mega-city Setting: Women at the Cross-roads of Patriarchy, Poverty, and Progress in Karachi.

Table - C

Distribution of the respondents according to their opinion regarding how their health been affected by the work

\begin{tabular}{|l|c|c|c|c|c|}
\hline Towns & Got weak & $\begin{array}{c}\text { Eyes have } \\
\text { been affected }\end{array}$ & $\begin{array}{c}\text { No mental } \\
\text { peace }\end{array}$ & $\begin{array}{c}\text { Due to the } \\
\text { tiredness often } \\
\text { fever occurs }\end{array}$ & $\begin{array}{c}\text { Row } \\
\text { total }\end{array}$ \\
\hline New Karachi & $46(64.79 \%)$ & $10(14.09 \%)$ & $12(16.90 \%)$ & $03(4.22 \%)$ & 71 \\
\hline Liaquatabad & $61(81.33 \%)$ & $02(2.67 \%)$ & $08(10.67 \%)$ & $04(5.33 \%)$ & 75 \\
\hline SITE & $40(46.51 \%)$ & $13(15.11 \%)$ & $31(36.04 \%)$ & $02(2.32 \%)$ & 86 \\
\hline Orangi & $41(56.17 \%)$ & $10(13.70 \%)$ & $09(12.32 \%)$ & $13(17.80 \%)$ & 73 \\
\hline Lyari & $39(59.09 \%)$ & $06(9.09 \%)$ & $16(24.24 \%)$ & $05(7.57 \%)$ & 66 \\
\hline Gulberg & $63(70.78 \%)$ & $02(2.24 \%)$ & $21(23.59 \%)$ & $03(3.37 \%)$ & 89 \\
\hline Gadap & $45(51.72 \%)$ & $14(16.09 \%)$ & $22(25.28 \%)$ & $06(6.89 \%)$ & 87 \\
\hline Baldia & $47(63.51 \%)$ & $02(2.70 \%)$ & $24(32.43 \%)$ & $01(1.35 \%)$ & 74 \\
\hline $\begin{array}{l}\text { North } \\
\text { Nazimabad }\end{array}$ & $29(34.52 \%)$ & $36(42.85 \%)$ & $14(16.67 \%)$ & $05(5.95 \%)$ & 84 \\
\hline Column total & 411 & 95 & 157 & 42 & 705 \\
\hline
\end{tabular}

The table- $\mathrm{C}$ showing the classification of the 705 out of 900 respondents who have been suffering from different health problems.

As been discussed earlier in this paper lack of data on women and work and social norms of segregation remain the two major blocks in making women's role in economic development visible. This invisibility was duly recognized as a major problem in the Pakistan country paper for the Fourth World Conference for Women at Beijing 1995. Despite the avowed commitment of the Government of Pakistan and of the nongovernment agencies to minimize this invisibility so that women's contribution to economic development is recognized nothing much has been achieved in this respect. This failure is amply acknowledged by Begum Mehnaz Rafi at a workshop on 'women employment concerns and working conditions in Pakistan' held on August 16, 2007 in Parliament Lodges, Islamabad. Mehnaz Rafi, the then Chairperson of National Assembly Attending Committee for Women Development, in her inaugural remarks giving an estimated number of eighty percent were women engaged in informal home based work out of 50 million people. However these eighty percent remain invisible in the country's economy since their contribution is not recognized as formal work. ${ }^{1}$

Women's life in Pakistan's stratified society is controlled by class, caste, regional and cultural variations. All women, irrespective of these variations share one common challenge: the obscurantist readings of the Qur'an and the Hadith and its forced implementation for determining women's status. Akram-Lodhi analysing this significant factor in women's lives in Pakistan writes that the conservatism of the society "ultimately manifest itself in the ability to control female labor and the ability to control female access to resources through the practice of seclusion" (Akram-Lodhi, 1996). 
The division of household labor is not dissimilar in industrialized countries. Although gender disparities in the overall work burden are less marked than in developing countries, women in the more affluent nations still spend far greater proportion of working hours than men in unpaid work (UNDP, Human Development Report, 2005).

This paper also analyses the circumstances due to which poor, illiterate and semieducated women overstrained with the heavy workload of their daily chores chose to work to earn money and supplement their family's income. This research, therefore, attempts to explore the question of women and work in the broader perspective by focusing on the lives of women belonging to low income group. These self-employed women are working hard but are not able to save their income. According to the findings of research one could be able to clearly identify the situation of Karachi.

Table - D

Distribution of the respondents according to their opinion regarding if they are able to save some amount from their personal income

\begin{tabular}{|l|c|c|c|c|}
\hline Towns & Yes & No & Sometimes & Row total \\
\hline New Karachi & $02(2 \%)$ & $98(98 \%)$ & - & 100 \\
\hline Liaquatabad & - & $99(99 \%)$ & $01(1 \%)$ & 100 \\
\hline SITE & $02(02 \%)$ & $98(98 \%)$ & - & 100 \\
\hline Orangi & $14(14 \%)$ & $86(86 \%)$ & - & 100 \\
\hline Lyari & $06(6 \%)$ & $92(92 \%)$ & $02(2 \%)$ & 100 \\
\hline Gulberg & - & $100(100 \%)$ & - & 100 \\
\hline Gadap & - & $100(100 \%)$ & - & 100 \\
\hline Baldia & - & $100(100 \%)$ & - & 100 \\
\hline North Nazimabad & - & $90(90 \%)$ & $10(10 \%)$ & 100 \\
\hline Column total & 24 & 863 & 13 & 900 \\
\hline
\end{tabular}

Table - D is showing distribution of the respondents according to their opinion regarding if they are able to save some amount from their monthly income. 863 out of 900 women are unable to do so. Only 24 women are saving their income and 13 were able to do so only at times.

The study conducted by Naqvi and Shahnaz regarding women's decision to work in Pakistan shows that "women who are older, better educated, female head of the household, or coming from smaller better off urban families are more empowered to take decisions on their own about whether to get a job or not. In contrast, younger, poorly educated women who are from larger families enter the labour market not out of their own choice. Decisions whether they go out and get a job are made by other members of the household at times even without their consultation" (Naqvi, \& Shahnaz 2002).

Very few efforts have been made by the Government of Pakistan for the betterment of the self-employed women. The Government of Pakistan, despite the recommendation given by The Commission of Inquiry for Women 1997 that Parliament should mandate 

and Progress in Karachi.

affirmative action to give women a fair chance to participate in all facets of national socio-political and economic life, has not justifiably moved ahead either for providing protective legislation for the self employed workers nor has offered institutional support to them (Commission of inquiry for women, 1997).

In this regard women should be provided the political stability and freedom which helps them to bring their problems infront of the public eye. The need for the better data analysis and evaluation is required here.

Last but not the least the business of self employment has brought some positive change in the lives of the self employed women in Karachi. It has raised their respect in the family and in the neighbourhood. The business has also boosted the self-confidence in these women. The following table shows this:

\section{Table - E}

Distribution of the respondents according to do they think that work has raised their self-confidence

\begin{tabular}{|l|c|c|c|}
\hline Towns & Yes & No & Row total \\
\hline New Karachi & $100(100 \%)$ & - & 100 \\
\hline Liaquatabad & $100(100 \%$ & - & 100 \\
\hline SITE & $100(100 \%)$ & - & 100 \\
\hline Orangi & $100(100 \%)$ & - & 100 \\
\hline Lyari & $100(100 \%)$ & - & 100 \\
\hline Gulberg & $100(100 \%)$ & - & 100 \\
\hline Gadap & $100(100 \%)$ & - & 100 \\
\hline Baldia & $98(98 \%)$ & $02(2 \%)$ & 100 \\
\hline North Nazimabad & $100(100 \%)$ & - & 100 \\
\hline Column total & 898 & 02 & 900 \\
\hline
\end{tabular}

Table - E This table places before us a major finding of this dissertation. 898 out of the 900 self employed women said their work and the gains they made out of it raised their self-confidence. A small minority, 2 respondents, do not have confidence.

Briefly, this study explores the identity of self-employed women as silent agents of social change. The most important object of this study is to make the self-employed women workers noticeable and to seek acknowledgment and acceptance for their contribution towards the country's economic growth and national earnings.

\section{End Notes}

1. www.pchr.org.pk/index files/Seminars/16-08-2007 


\section{References}

Lodhi, Akram \& Haroon A. (1996) “You Are Not Excused from Cooking': Peasants and Gender Division of Labour in Pakistan” In Feminist Economics 2 (2), p. 97.

Becker, Kristina Floodman. (2004) Fact Finding Study: The Informal Economy Stockholm, SIDA.

Carr, M. Chen, M. A. \& Tate, J. (2000) “Globalization and Home Based Workers" In Feminist Economics 6 (3): p. 137.

Chen, Martha, A. (1996) Beyond Credit: A Conceptual framework, in Beyond Credit: A Subsector Approach to Promoting Women's Enterprises, Ottawa, Aga Khan Foundation, Canada. pp. 4-32.

Commission of Inquiry for Women, (1997) Report of the Commission of Inquiry for Women, Islamabad, pp. 46-8.

Doanne, Donna L. (2007) Living in the Background: Home Based Women Workers and Poverty Resistance. Home Net Soth East Asia, Manchestar Chronic Poverty Reserach Centre Working Paper, 97, p.2.

Gurley, C. \& Tami, (etal.) (2009) Self Employed Women and Time Use http://purl.access.gpo.gov/GPO/LPS109714 retrieved on March, 2010.

Home Net South Asian and Institute of Social Studies Trust (2006) Social Protection for Home Based Women Workers in South Asia: Learning from Action and Research New Delhi, ISST, p.6.

ILO (2002) Women and men in the informal sector economy: A statistical picture. Geneva, p. 14.

IIhai, Nadeem (2001) 'Children's Work and Schooling: Does Gender matter? Evidence from Peru LSMS Panel Data', World Bank Policy Research Working Paper No. 2745, World Bank, Washington, D.C., p. 4.

Jose, Sunny. (2007) Women, paid work, and empowerment in India: A review of evidence and issues, New Delhi, Centre for Women's Development Studies, p. 11.

Kamerman, Sheila B. (2002) 'Early Childhood Care and Education and other family Policies and Programs in South-East Asia', Early Childhood and Family Policy Series, No. 4, United Nations Educational, and Cultural and Scientific Organization, Paris, p. 23. 

and Progress in Karachi.

Mies, Maria (1982) "The Dynamics of the Sexual Division of Labour and Integration of Rural women into the World Market" in Lordes, Beneria(ed) Women and Development: The Sexual Division of Labour in the Rural Societies, p.10. (Quoted in "Globalization and Women's Paid Work: Expanding Freedom?” by Crhistine M. Koggel in Feminist Economics, 9 (2-3, 2003), p.179.).

Naqvi, Zareen \& Shahnaz Lubna (2002) “How do women decide to work in Paksitan” In The Pakistan Development Review, 41 (4) p. 510.

Sinha, Shalini (2006) Rights of Home based Workers, New Delhi, National Human Rights Commission of India, p. 14.

UNIFEM (2009) Progress of The World's Women 2008/2009: Who Answers to Women? Gender \& Accountability.

United Nation Development Programme, Human Development Report (2005) International cooperation at a cross roads: Aid, trade and security in an unequal world, Oxford University Press for UNDP, New York, Table 25, p. 315.

Nasreen Aslam Shah is a Ph.D Professor in the Department of Social Work and Director of the Centre of Excellence for Women's Studies, University of Karachi.

Muhammad Faisal Zia is a Ph.D scholar at the Department of Social Work, University of Karachi. 